\title{
Economic and Social Council
}

Distr.

GENERAL

E/CN.4/2001/43

February 2001

Original: ENGLISH

COMMISSION ON HUMAN RIGHTS

Fifty-seventh session

Item 9 of the provisional agenda

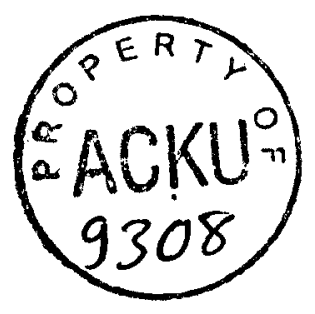

QUESTION OF THE VIOLATION OF HUMAN RIGHTS AND FUNDAMENTAL FREEDOMS IN ANY PART OF THE WORLD

Report on the situation of human rights in Afghanistan submitted by

Mr. Kamal Hossain, Special Rapporteur, in accordance with

Commission resolution 2000/18

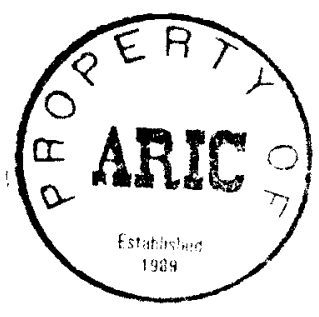


E/CN.4/2001/43

page 2

\section{CONTENTS}

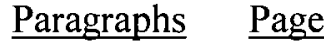

Executive summary

Introduction

$1-6$

I. DEVELOPMENTS AIMED AT PROMOTING THE PEACE

PROCESS, SEPTEMBER - DECEMBER 2000

$7-12$

II. CONTINUATION OF CONFLICT,

JULY 2000 - JANUARY 2001

$13-18$

III IMPACT OF CONTINUING CONFLICT: MASSIVE

DISPLACEMENT

$19-39$

A. Patterns of displacement .......................................... $19-26$

B. Nature and status of displacement .............................. $27-35$

C. New refugee flows ................................................ $36-39$

IV. HUMAN RIGHTS SITUATION,

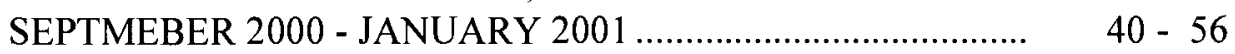
A. Impact of armed conflict on human rights and
violations of international humanitarian law
$40-44$
B. Health
45
C. Education
$46-47$
D. The media
48
E. Women
$49-52$
F. Food.
$53-55$
G. New decree
56

V. NEED FOR A STRATEGY OF CHANGE ….......................... 57 - 59

VI. CONCLUDING OBSERVATIONS ......................................... $60-65$ 


\section{Executive Summary}

This is the fifth report of the Special Rapporteur of the Commission on Human Rights on the situation of human rights in Afghanistan. The fourth report was made following a visit to the Islamic Republic of Iran where refugees in Mashhad and Tehran had been interviewed.

The Special Rapporteur had proposed a visit to Afghanistan in September 2000. The Taliban authorities, however, had denied him the opportunity to visit. The Special Rapporteur again addressed a request to the Taliban authorities to visit locations in Afghanistan in January 2001. They replied that they were not able to receive him because of their urgent preoccupations.

The efforts of the Special Representative of the Secretary-General aimed at securing an agreement by the two warring parties to initiate a process of dialogue resulted in separate letters being addressed to him by the Talilban and the United Front in which they agreed to enter into a process of dialogue under the Secretary-General's good offices aimed at bringing about, in the shortest possible time, an end to the armed conflict in Afghanistan through political means. The agreement signed by the Taliban and the United Front on 2 November 2000 was the first time the two warring sides have committed themselves in writing to a process of dialogue to achieve a political settlement, which suggests that they acknowledge that a military solution is not possible. It is also the first time that they have committed themselves not to abandon the negotiating process until all the items on the agenda have been examined. A distinctive feature of this agreement is that it is an agreement to a process, unlike earlier agreements, which focused on the holding of meetings.

Half a million Afghans left their homes and became displaced during 2000 and early 2001, heading towards impoverished cities and other areas. More people are expected to be on the move over the next several months. According to UNHCR officials in Pakistan, there has been a marked increase in new arrivals in recent months (September 2000 - January 2001) and a significant number of these are from northern Afghanistan. Reports from UNHCR sources at the end of January 2001 indicate that the new refugee flows into Pakistan are continuing. These refugee flows are caused by the interrelated impact of conflict, drought and hunger. 
All the warring parties have been guilty of grave breaches of international humanitarian law. Their war-making is supported and perpetuated by the involvement of Afghanistan's neighbours and other states in providing weapons, ammunition, fuel and other logistical support. State and non-state actors across the region and beyond continue to provide new arms and other material, as well as training and advisory assistance. The arms provided have been directly implicated in serious violations of international humanitarian law. These violations include aerial bombardments of civilian targets, indiscriminate bombings, rocket and other artillery attacks on areas populated by civilians, reprisal killings of civilians, summary executions of prisoners, rape and torture.

There are credible reports that Taliban forces under the command of Mullah Dadallah systematically executed ethnic Uzbek prisoners in Samagan province in early May 2000. Accounts of the number of killings and the precise burial sites vary, but the killings appear to have been large-scale and are reported to have taken place near the Rubatak Pass, along the road from Mazar-i-Sharif to Pul-i-Khumri.

On 29 December 2000, Hezb-e-Wahdat forces captured Yakawlang. After the Taliban recaptured Yakawlang in early January 2001, there were numerous reports of widespread summary executions of civilians by the Taliban were mostly in villages around Nayak (the estimates range from one hundred to several hundred), as well as of mass arbitrary arrests. Eyewitnesses also report that both parties to the conflict violated the neutrality of medical facilities in the district and generally disregarded the rights of civilians to be treated as non-combatants. In addition, at least one United Nations employee is unaccounted for and has not been seen since 7 January. Aid agency personnel are reported to have been killed.

According to a UNICEF Afghanistan paper, after more than two decades of . conflict, Afghanistan has some of the worst education indicators in the world. Access is low at all levels, especially for girls but also for boys. According to recent UNESCO data, as few as 3 per cent of Afghan girls and 39 per cent of boys in the relevant age groups may be receiving some form of primary education, the quality of much of which remains poor.

With regard to female employment, a major setback occurred in July 2000 when the Taliban issued a decree of law banning Afghan women from working in aid agencies, except in the health sector. This law not only represents a gross violation of the rights of Afghan women but it also narrowed 


\section{E/CN.4/2001/43 \\ page 5}

considerably the assistance community's access to more than 50 per cent of the Afghan population, since in Afghanistan only women aid workers can work with female beneficiaries. The United Nations Coordinator and other senior United Nations staff made several visits to Kabul and Kandahar in an attempt to negotiate the withdrawal of the law. A decree was promulgated by Mullah Omar on 8 January 2001 to apply capital punishment to Afghans who converted from Islam to either Judaism or Christianity.

Throughout Afghanistan the impact of the war on the economic infrastructure has been devastating. Transport and communication facilities are derelict. For Afghans, there are few job opportunities outside the subsistence economy on the one hand and the criminalized economy on the other. Close to a miliion people are estimated to be vulnerable, hungry and at risk as a result of the loss of their agricultural output, combined with lack of other opportunities to earn enough money to pay for essential food. A January 2001 report of a United Nation-sponsored health survey in northern Afghanistan found alarming levels of malnutrition among children, and aid officials have warned that the situation could worsen dramatically in coming months. High rates of chronic malnutrition are widespread in Afghanistan owing to extreme poverty; regular illness and a severe drought are exacerbating the problem.

There can be little doubt that all segments of the Afghan population are united on the imperative need for change in the prevailing situation. It is important to underline that a significant improvement in the overall human rights situation requires a comprehensive strategy in which carefully orchestrated and coordinated moves are made at both the macro and micro levels. Such moves should not be seen as alternatives, but as being complementary. Micro-level incremental measures must clearly be persevered with and humanitarian assistance provided to strengthen the coping mechanisms of the population. However, this cannot be a substitute for resolute action by the international community to bring about a basic framework change.

There is a clear need to initiate and sustain a process in which all segments of the Afghan population, inside and outside Afghanistan, can devise and establish participatory institutions, not only at the community but also at the national level. They would include institutions of governance which would meet the test, of being based on the consent of the population and which would enable the Afghans to participate in the making of laws and policies and in their implementation. Given the multi-ethnic character of Afghanistan, and also given that there is consensus among the various ethnic 
E/CN.4/2001/43

page 6

groups that they are committed to a unified Afghanistan, the national institutions must be multi-ethnic, broad-based and truly representative. This should be the overriding aim and ultimate goal of a process of sustained negotiation undertaken in good faith.

The international community, acting in particular through the security Council, would be expected to discharge its fundamental obligation to protect the people and territory of Afghanistan from external interference and from the destructive armed conflict which continues to be externally supported. The sufferings of the Afghan people are compounded by the use of the territory of Afghanistan for various forms of cross-border criminal activity, including drug trafficking. It is an indispensable condition for an overall improvement in the human rights situation that effective action is taken to prevent such activities.

\section{Introduction}

1. This is the fifth report of the Special Rapporteur of the Commission on Human Rights on the situation of human rights in Afghanistan. The first three reports were submitted following visits to Kabul and Kandahar and to Islamabad, Peshawar and Quetta, where Afghan refugee groups were interviewed. The fourth report was submitted following a visit to the Islamic Republic of Iran, where Afghan refugees in Mashhad and Tehran were interviewed.

2. The Special Rapporteur had proposed a visit to Afghanistan in September 2000. The Taliban authorities, however, denied him the opportunity to visit. The High Commissioner for Human Rights wrote on 5 september 2000 to Mullah Mohammed Omar, the Taliban Supreme Leader, urging that the special Rapporteur=s request be reconsidered, and stating that it was a principle of great importance that authorities cooperate with United Nations special rapporteurs. The General Assembly, in its resolution 55/119 of 4 December 2000, called upon the Taliban to accommodate the forthcoming visit of the Special Rapporteur on the situation of human rights in Afghanistan. The Secretary-General, in his report dated 20 November, 2000 to the General Assembly and the Security Council (A/55/633-S/2000/1106, the SecretaryGeneral's report), regretted that the Taliban movement continued to deny access to the Special Rapporteur of the Commission on Human Rights on the situation of human rights in Afghanistan. He took note of the Special Rapporteur=s latest report (A/55/346), which highlighted "the alarming situation regarding human rights in Afghanistanæ. The Special Rapporteur 
addressed a request to the Taliban authorities proposing a visit in January 2001, in reply to which they apologized for being unable to receive him because of their urgent preoccupations. It is hoped that a visit may be possible some time in March.

3. The Special Rapporteur had proposed visits to Pakistan in September 2000 but was advised that the Minister for Foreign Affairs and senior officials of the Ministry would be in New York in September 2000 attending the Millennium Sumit. The Special Rapporteur then arranged to visit New York where he met the Minister for Foreign Affairs of Pakistan, H.E. Mr. Abdus Sattar. He was also able to meet with the chief of the Afghanistan Headquarters at the Ministry for Foreign Affairs of Iran, H.E. Mr. M.E. Taherian. In addition, the Special Rapporteur met the Permanent Representative of Afghanistan to the United Nations, H.E. Ambassador Farhadi, to review developments in Afghanistan. In New York, the Special Rapporteur met the Chef de Cabinet of the Secretary-General, Mr. Iqbal Riza, the Assistant Secretary-General for Political Affairs, the Personal Representative of the Secretary-General for Afghanistan and Head of the United Nations Special Mission to Afghanistan (UNSMA), the Emergency Relief Coordinator, a.i., the Special Adviser to the Secretary-General on Gender Issues and the Advancement of women and other senior United Nations officials.

4. On the occasion of presenting his report to the General Assembly on 24 October 2000, the Special Rapporteur had the opportunity to call on the Secretary-General and to bring to his attention specific aspects of his report.

5. On 30 October 2000, the Special Rapporteur participated in a meeting with representatives of the Office of the High Commissioner for Human Rights, the Office of the Coordination for Humanitarian Affairs, the Department of Political Affairs, UNSMA and the non governmental community aimed at arriving at a better understanding of the situation in Afghanistan and the human rights challenges confronting the United Nations. There was a consensus that Afghanistan is in a deep human rights crisis affecting every aspect of life. Concern was shared that donor fatigue and other factors had resulted in fading interest in and focus on Afghanistan, which was unfortunate. OHCHR could take initiatives to ensure that the human rights situation in Afghanistan receives the attention and resources necessary to encourage meaningful and positive change. In this context, a comprehensive analysis of the human rights situation in Afghanistan, which was proposed at that meeting, could be useful. Its credibility and usefulness would depends on its independence, It would be 
commissioned by OHCHR and the Special Rapporteur would be associated with such an exercise. The special Rapporteur could make his time available for this purpose without claiming any additional resources.

6. On 27 November 2000, the Special Rapporteur renewed his requests to visit Kabul, Kandahar and other locations in Afghanistan, addressed to Mullah Mohammad Omar, the Taliban Supreme Leader, and to Mullah Wakeel Ahmed Mutawakil, the Taliban Minister for Foreign Affairs.

\section{DEVELOPMENTS Aimed AT PROMOting the PEACE PROCESS, SEPTEMBER - DECEMBER2000}

7. At the Millennium Sumit, the Secretary-General discussed the situation in Afghanistan and the ongoing peace-making efforts by UNSMA with a large number of Heads of State, including the Presidents of Kazakhstan, the Islamic Republic of Iran, and the Russian Federation, as well as the Chief Executive of the Islamic Republic of Pakistan and Ministers for Foreign Affairs.

8. During the Ninth Summit of the Organization of the Islamic Conference (Doha, Qatar, 12 and 13 November 2000), the secretary-General participated in separate discussions on the issue of Afghanistan, in particular with the Heads of State of the Islamic Republic of Iran and Pakistan. Mr. Francesc Vendrell, the Personal Representative of the Secretary-General also attended the Ninth Sumit and took part in several of those meetings.

9. Since his appointment in February 2000, the Personal Representative of the Secretary-General had been engaging in discussions with the Afghan parties, as well as with the Governments of the "six plus two" group on Afghanistan and other concerned and interested Governments. While developing and strengthening his contacts, he began to evolve, in coordination with his interlocutors, some idea as to how a peace process under the auspices of the United Nations might be structured. The Personal Representative met the Taliban Supreme Leader on 5 september 2000 in Kandahar, the Taliban Minister of Foreign Affairs, Wakil Ahmad Mutawakkil and other ministers and also met the President of the Islamic State of Afghanistan, Professor Burhanuddin Rabbani, the Acting Minister for Foreign Affairs, Dr. A. Abdullah, and Commander Ahmad Shah Massoud. The discussions with the Personal Representative covered the following topics among others: the repeated demand of the security Council in its various resolutions and statements for an immediate ceasefire; the non-targeting of civilian populations in the course of the fighting; other humanitarian and human rights matters; issues of terrorism and poppy cultivation; and the views of his interlocutors on the 


\section{E/CN.4/2001/43 \\ page 9}

establishment of a broad-based, multi-ethnic and representative government. These discussions also touched on relations with third countries. It is noteworthy in this connection that each side vehemently complained about persistent outside interference in support of the other side.

10. The positive element which has emerged is that both warring sides have expressed their willingness to consider a negotiated solution to the conflict. The Personal Representative's efforts resulted in addressing the Taliban and the United Front separate letters to him in which they agreed to enter into a process of dialogue under the secretary-General=s good offices aimed at bringing about, in the shortest possible time, an end to the armed conflict in Afghanistan through political means. They also agreed that this process should be conducted either through direct meetings between the two sides, either with the active participation of the secretary-General or that of Personal Representative, or indirectly through their intermediation. Notable in the agreement, dated 2 November 2000, was the commitment of the two sides to participate in the dialogue with serious intent and in good faith; and not to abandon the process unilaterally, but rather to pursue it without interruption until the negotiating agenda, to be agreed by the two sides was exhausted. Following this agreement, the Personal Representative began to shuttle between the two sides to discuss elements for the negotiatirig agenda. If there was a sufficient basis for an eventual agreement, he hoped to schedule a meeting between the two sides, possibly before the end of 2000 .

\section{Loya Jirga}

11. The Personal Representative had two meetings with the former King of Afghanistan, Zaher Shah, the latest in October 2000, to exchange views on the situation in Afghanistan and to discuss the former King=s ideas on how a loya jirga, a traditional grand assembly, could be convened inside Afganistan. He also held a series of meetings in Pakistan, Saudi Arabia, the Islamic Republic of Iran and Germany with independent Afghan personalities including many who support the former King=s proposal for the convening of an emergency loya jirga. In this context, the secretary-General in his report stressed that the criterion for participation in the shaping of Afghanistan's future cannot be the holding of weapons, but that non-fighting Afghans, both inside and outside the country, have much to contribute and need to be involved in deciding the ultimate destiny of their country.

12. The focus of the Personal Representative=s discussion has been the implications for regional and international security of the situation in 
E/CN.4/2001/43

page 10

Afghanistan, the prospects for peace, the means for achieving a lasting settlement, the question of human rights and logistics.

il. CONTINUATION OF CONFLict, JUly - JANUARY 2001

13. The Secretary-General=s report records that: AThe intensity of this year's fighting indicates that the flow of arms and other war-making materiel into Afghanistan continued unabated and, during the last few months, even rose to new levels. The season=s full-scale fighting started in the north of Kabul with two vigorous offensives by the Taliban forces on 1 and 9 July .

14. Detailed descriptions of the fighting during the spring and summer period are given in the Secretary-General=s previous reports to the General Assembly and the security Council and were summarized in the special Rapporteur $=s$ interim report $(A / 55 / 346$, paras $21-26)$.

15. In september and early October, Taliban forces secured wider areas around Taloqan and embarked upon a series of attacks to the north, capturing the districts of Khwajaghar, Dashti Archi and Imam Sahab in Takhar Province. At that point, Badakhshan Province was the sole province left entirely under the control of the United Front. On 14 October, the United Front launched a successful counter-attack, recapturing the districts of Imam Sahab and Dashti Archi and the United Front forces advanced towards Talogan from the east and north. After 10 days of progress, the United Front counter-offensive ebbed and the Taliban were able to push the attacking forces back. As of 5 November, the confrontation lines were more or less the same as at 13 October, and the situation appeared to have developed into a stalemate.

16. On 20 December 2000, Hezb-e-Wahdat forces affiliated with the United Front took over the area of Yakawlang in Bamyan Province in Hazarajat, central Afghanistan, from the Taliban. The area was recaptured by the Taliban on 7 January 2001 .

17. On 19 January, the Secretary-General issued a statement expressing concern about reports of deliberate targeting and killing of civilians by the Taliban during recent fighting in the Yakawlang area. He deplored the killing of civilians and demanded that the Taliban take immediate steps to control their forces. More than 100 civilians, including Afghan humanitarian workers, were alleged to have been killed. 
18. From reliable sources, there were confirmed reports of widespread killings of innocent civilians in the Yakawlang district of Bamyan Province. The OCHA was unable to provide precise details of the number of civilians killed, but indicated that civilians who were believed to be sympathetic to the United Front were targeted by the Taliban and that those killed were noncombatants, not involved in the fighting. The fighting and massacres gave rise to widespread displacement of civilians. According to a United Nations statement, of the estimated 90,000 inhabitants of Yakawlang district, approximately one third had fled their homes.

\section{IMPACT OF CONTINUING CONFLICT: MASSIVE DISPLACEMENT}

\section{A. Patterns of displacement}

19. The first movements of internally displaced persons (IDPs) of the summer occurred in early August after a Taliban assaul on Nahrain and Burqa (Baghlan Province) and Ishkamish (Takhar Province) in late July. Populations moved primarily into the upland areas of southern Baghlan (e.g. Khost wa Fereng, Andarab) and southern Takhar, as well as some towards Taloqan.

20. Displacement continued as the Taliban moved eastwards towards Taloqan, when populations from areas west (e.g. Bangi) and immediately north of the city (e.g. Baharak) moved either into the city or northwards. At this stage the first movements of IDPs from Taloqan into Badakhshan Province (to Keshem and Faizabad) occurred, though the numbers were moderate. A higher level of displacement occurred from Archi (Kunduz Province) and Khaja Ghar (Takhar Province) eastwards across the Kokcha River to Dasht-i-Qala, Khoja Bahauddin and Rustaq (Takhar) as the conflict spread.

21. A second large wave north and east from the Taloqan area into Kalafghan and Farkhar (Takhar) and Keshem (Badakhshan) and to a lesser degree Faizabad occurred followed the final capture of Taloqan on 5 september after over a month=s fighting. Many of the IDPs subsequently moved further afield, including some who looped round into Taliban-controlled Taloqan. After the fall of Tangi Farkhar around 1 October, the majority of IDPs moved out of Keshem. Further eastwards, increased displacement occurred across the Kokcha River as conflict spread within Khoja Ghar (Takhar), emptying the district. Many of those IDPs, and the host population, subsequently moved within Dashtii-Qala and into Khoja Bahauddin districts. With few public buildings, the 
E/CN.4/2001/43

page 12

districts of Khoja Bahauddin and Dashti-i-Qala quickly became saturated and large numbers of IDPs consequently remained under soft shelter outside.

22. Counting the IDPs proved to be difficult in many cases owing to their dispersion and mixing with the host populations, their high mobility of IDPs, members of the local population masquerading as IDPs and short-range movements by local populations into neighbouring areas. By the first week of October, surveys indicated that there were approximately 11,000 IDP families in 12 districts of Kunduz, Takhar and Badakhshan Province. Many districts of origin have now been totally emptied.

23. The reported killings in the course of the military offensives in the Yakawlang area of Hazarajat have led to massive displacement, reportedly of some 30,000 persons out of an estimated population of 90,000, and to the increased suffering of a population that had already been badly affected by the drought and was then exposed to sub-zero temperatures and hunger.

24. According to a report of 31 January 2001 by the Office of the United Nations Coordinator for Afghanistan, over 110 displaced persons in camps in Herat died due to extreme cold on the night of 29/30 January. The number of such deaths is expected to rise as the area continues to experience extremely cold weather, temperatures falling to as low as $-25^{\circ} \mathrm{C}$. The same report put at approximately 80,000 the number of displaced persons in six camps outside Herat City, families having started to leave their homes as early as June 2000 because of the severe drought which resulted in crop losses averaging 75 per cent and a 50 per cent reduction in livestock assets.

25. According to an assessment by the United Nations office for the Coordination of Humanitarian Assistance to Afghanistan (UNOCHA) in early February 2001, the situation in Afghanistan deteriorated seriously in the course of 2000 and early 2001. Half a million Afghans have left their homes, heading towards impoverished cities and other areas. There chances of finding work are low and if they do, they will still not be able to feed their families because of falling wage rates. In some areas a person would have to work for an entire week just to provide one meal for the family. More people were expected to be on the move over the next several months. An appeal had been made at an emergency meeting of donors to respond immediately to the 2001 Appeal for Afghanistan and specifically to provide US\$ 3.5 million for nonfood items including shelter, blankets and clothing, Us\$ 3.2 million in cash to complement food for work programmes and US\$ 600,000 for seeds. As of the 
end of January 2001, only US\$200,000 of the US\$ 3.5 million requested for non-food items had been pledged.

26. An eyewitness account from a most reliable source in January 2001 recorded the suffering, especially of women and children, in IDP camps in Mazar-i-Sharif, a substantial extract from which is contained in annex I to this report.

\section{B. Nature and status of displacement}

27. In general, the majority of the IDP population are rural in origin and possess few general assets and very limited food stocks. Many who were able to bring food stocks with them have exhausted them. Those from Khoja Ghar, Hazar Bagh (Takhar) and Archi (Kunduz), at present in districts east of the Kokcha (principally Dasht-i-Qala and Khoja Bahauddin), are considered to be highly vulnerable on account of (a) the impact of the autumn 1999 conflict on their areas of origin and the huge losses of property and assets which resulted; (b) the impact of the current drought on the rainfed agriculture which predominates in those areas and the very low harvest which they obtained this year; (c) the similar impact of the drought on host communities, whose ability to support them in terms of food and housing is restricted. It is expected that these IDPs will have extremely limited access to food supplies, other than food aid.

28. The majority of IDPs from Taloqan (who moved to Keshem) are of urban origin. A minority among them have been able to transfer their businesses to Keshem and are consequently self-reliant. Most, however, have limited assets and resources and include a large proportion who had previously been displaced, or moved as economic migrants, to Taloqan. Among the latter, those who had enough funds were the first to flee from Taloqan to Faizabad.

29. The shelter situation for IDPs is mixed. Those in Dasht-i-Qala and Khoja Bahauddin are predominantly in the open or sleep outdoors in the compounds of houses belonging to local people; those in Rustaq are in spare or intentionally vacated rooms in local houses; those in Keshem are either inside with local people or in compounds, outdoors; and those in Faizabad are divided either living in public buildings, with local people or temporary shelter. The shelter situation in north Takhar is a primary concern. Large numbers are living in the open in Dasht-i-Qala and Khoja Bahauddin, and several sizeable spontaneous camps have emerged. 
E/CN.4/2001/43

page 14

30. In early October, a joint United Nations and NGO mission found over 10,000 IDPs in Baghlan Province in northern Afghanistan, with 15 to 20 more families arriving each day from Nahrin, Burqa and Ishkamish. Most public buildings in Puli-Kumri and Baghlan city were crammed with IDPs, single rooms housing 8 to 10 families and men having to sleep outside at night. The estimated number displaced in Takhar and Badakhshan Provinces by fighting between advancing Taliban troops and the United Front was about 60,000.

31. In early December, the Office of the United Nation High Commissioner for Refugees (UNHCR) made a formal request to the Government of Tajkistan to admit up to 10,000 displaced Afghans, mostly women and children of Tajik and Uzbek origin, marooned on the islands of the Pyanj River on the Tajik/Afghan border as a result of refusal of the Government of Tajikistan to grant them asylum. The displaced persons, who had been stranded on the islands since mid-November, were suffering from sub-human conditions and had been subjected to frequent shelling by the Taliban forces positioned across from the closed border with Tajikistan. UNHCR indicated that the displaced people had no access to health facilities, an inadequate supply of food and were not protected against the cold.

32. The special Rapporteur visited the IDP compound in the former soviet Embassy in Kabul in September 1999. Subsequent visitors to that compound have reported that the access of the IDPs to the city is controlled by the Taliban and women are reportedly not permitted to leave the area without a written medical note to seek health care. The living conditions in the compound, which had been observed to be quite poor when the special Rapporteur visited it, have obviously not improved, since the subsequent visitors reported that clean water and adequate toilet facilities were still lacking. Even though the IDP population was largely composed of women and children, reportedly more toilets had been constructed for men than for women. The women interviewed confirmed their fragile and vulnerable states. Many women had been separated from their husbands some of whom they feared had been killed in the fighting and others were detained in prison.

33. The Guiding Principles on Internal Displacement recognise the unique situation of internally displaced women and girls and call for measures to protect them. Since the majority of the IDP population consists of women and children, it is important to underline the need for the Guiding Principles to be better understood by agencies delivering humanitarian assistance to the IDPs. An international NGO has urged that the agencies concerned need to take new approaches to assisting internally displaced persons; in particular, they 
need to focus greater attention on protection, on sustaining livelihoods, on self-determination and independence-building activities, on involving women in the peace and reconciliation process and on managing community development activities. It has also made the following recommendations, which merit serious consideration:

(a) Although extremely difficult in war zones, sex disaggregated data collection is crucial to providing effective programing for internally displaced people. Access to good representative data prevents mistakes like the example cited above where more toilets for men were built in a population of mostly women and children.

(b) Agencies need to engage gender specialists to assess internally displaced persons settings so that appropriate actions can be taken to address the different needs and rights of women and men.

(c) Given that the level of literacy of women in many displacement situations is low, information on entitlements and programming should be provided in oral or visual formats for non-literate women.

(d) Lessons-learned documentation from various internally displaced settings need to be published and distributed to enable programmes to be better implemented and past mistakes avoided.

(e) Internally displaced women must be involved in planning, designing and monitoring of programmes. In cases where displaced women have input and ownership in programme activities, as well as in reintegration processes, the risks of gender rights abuses occurring are reduced.

(e) The Guiding Principles on Internal Displacement should be translated into local languages and distributed to women.

(f) Special arrangements should be made to distribute food directly to women and to involve them in the process of distribution and monitoring.

(g) United Nations agencies should consider promoting an inter-agency mechanism to ensure institutional responsibility for gender in situations of displacement.

(h) More attention is needed on programmes that encourage selfdetermination and community development efforts and less on short-term emergency measures.

(i) Periodic gender audits should be commissioned by the lead agency in a given setting of internal displacement to assure that gender issues are addressed according to international standards and guidelines.

34. Longer-term perspectives on the situation of the IDPs are provided in a paper entitled AAssistance and human rights in war-torn Afghanistan:

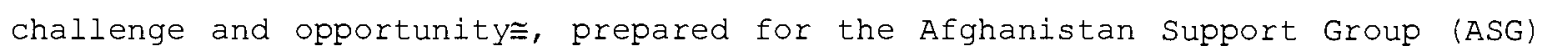


E/CN.4/2001/43

page 16

meeting in Montreux, Switzerland in December 2000: AConflict-related displacement included a refugee population that numbered more than 6 million at the end of the 1980s. A significant number of these refugees have returned but Afghans continue to be displaced and seek refuge and a means of survival outside the country. $\cong$ The paper cites a 1999 UNHCR survey which found that 27 per cent of returnees did not hold regular jobs, 21 per cent found their houses Acompletely destroyed?, 46 per cent had no access of any kind to health care services and 79 per cent of families with school-age children did not have any children at school. It is further noted that all key indicators, including those for infant and maternal mortality, life expectancy and vaccination coverage, show that Afghanistan is one of the three most difficult places in the world in which to survive.

35. The ASG paper succinctly depicts the situation which needs to be addressed if human rights are to be protected against further deterioration:

AIt is increasingly apparent that the coping capacity of those who are most vulnerable has been severely weakened as a result of the war; the majority of the population struggles to survive at near subsistence levels. The situation of females, including in particular female-headed households, is of particular concern given the many old and new restrictions that limit their ability to provide for themselves and their families. Indeed, for women and men alike there are very few job opportunities outside the subsistence economy; for many, the only available option is the criminalized economy or re-location to another area. Afghanistan=s socio-economic indicators are well known and are likely to get worse as the drought takes its toll and the underlying causes of poverty and underdevelopment are largely ignored. It is this reality - coupled with the knowledge of what was possible in pre-war Afghanistan - which should motivate the international community to tackle the dynamics which contribute to a worsening of the crisis and

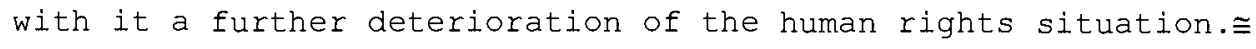

\section{New refugee flows}

36. According to UNHCR officials in Pakistan, there has been a marked increase in new arrivals in recent months (September 2000-January 2001). A significant number of these arrivals are from northern Afghanistan. Traditionaly, the majority of Afghan refugees, including new arrivals passing into Pakistan at this time of the year, come from the eastern region 
and other nearby provinces. The Government of Pakistan banned the entry of new refugees from Afghanistan on 9 November 2000, citing Asecurity and economic considerations $\cong$. Pakistani officials initially asserted that they could not cope with the additional influx of Afghan refugees, in the absence of international support. They also expressed concern that United Front might infiltrate into Pakistan in the refugee influx, supporters tasked with carrying out acts of sabotage. Pakistani border guards continued to allow entry to Afghans who could produce identification documents establishing prior refugee status in Pakistan, as well as to Afghans without such papers if they had a note from the Taliban authorities attesting their status as prior refugees, traders, or NGO or government workers. Obviously, persons fleeing from the northern areas in the face of Taliban military operations who were among the most vulnerable were not in these categories. A reliable source indicates that many of those seeking to cross into Pakistan, some of whom were stranded in the samar Khel camp at Jalalabad, had been affected by the conflict in the north, and that members of the Ismaili (Shiite) minority were reportedly buying their exit from Afghanistan to destinations in Pakistan.

37. According to reliable reports, several thousand Afghan refugees were struggling to get near the Pakistani border, only to be beaten back by their Taliban compatriots. Even young boys and old men were not spared. Interviewees indicated that, while crossing at the Torkham border, Afghans with possessions (clothes, food, hens, a goat or two) faced a gauntlet of border police who harassed them for money. From reports based on lengthy observation and interviews, it appeared that some families were stopped up to six times. On each occasion they had to hand over money.

38. Large-scale returns following 1992 have largely stopped and at present it is estimated that some four million refugees remain in Pakistan and Iran, many of them children born of refugee parents. In pakistan, in the past 10 years, it is estimated that some 600,000 children have been born to camp residents alone. The Afghan refugee caseload remains the largest in the world: the annual UNHCR budget allocation to the region this year amounted to approximately 42 million dollars, - only 5 per cent of its overall budget.

39. Reports at the end of January 2001 from UNHCR sources indicate that the new refugee flows into Pakistan are continuing. The situation is evolving by the day and growing increasingly complex Adue to the appalling situation inside Afghanistanæ. In Pakistan, a makeshift site, referred to as Jalozai, close to the border is reported to host over 70,000 new arrivals. The UNHCR 


\section{E/CN.4/2001/43 \\ page 18}

sources further indicate that of the 14,000 or so Afghans at this site, the great majority are new arrivals since september and that, if the situation continues to deteriorate at such a rapid pace, UNHCR will face major problems in identifying and securing new sites in Pakistan. These refugee flows are caused by the interrelated impact of conflict, drought and hunger.

\section{HUMAN RIGHTS SITUATION: SEPTEMBER - JANUARY 2001}

A. Impact of armed conflict on human rights and violations of international humanitarian law

40. The Human Rights Watch World Report 2001, Asia Overview, summarizes once again the terrible impact of the more than 20-year-long armed conflict in Afghanistan. It records that during that time Afghanistan has lost a third of its population. Some 1.5 million people are estimated to have died as a direct result of the conflict. Another five million (or more) fled as refugees to Iran and Pakistan; others became exiles elsewhere abroad. the Afghan conflict has not only produced the largest refugee population in recent decades, but also some of the largest numbers of internally displaced persons. Afghanistan has the world's lowest life expectancy and literacy rates and the highest rates of infant, child and maternal mortality. With somalia, it is ranked as one of the world=s two hungriest countries.

41. The Human Rights watch report confirms earlier findings, reflected in the reports of the present special Rapporteur and his predecessors, that all the warring parties have been guilty of grave breaches of international humanitarian law. Their war-making is supported and perpetuated by the involvement of Afghanistan=s neighbours and other states in providing weapons, ammunition, fuel and other logistical support. State and non-state actors across the region and beyond continue to provide new arms and other material, as well as training and advisory assistance. The arms provided have been directly implicated in serious violations of international humanitarian law. These include aerial bombardments of civilian targets, indiscriminate bombings, rocket and other artillery attacks on areas populated by civilians, reprisal killings of civilians, summary executions of prisoners, rape and torture. Further, on the basis of extensive research in Afghanistan and adjacent countries, the report claims that major transit routes used to move arms and other equipment, the suppliers and the role of state and non-State actors have been identified. 


\section{E/CN.4/2001/43 \\ page 19}

42. The ASG paper (see para. 34 above), note that experience in Afghanistan since the beginning of the war points to a pattern of abuse by all warring parties that demands greater attention to the need to augment the protection of civilians and to erode the prevailing climate of impunity. Further, it notes that in the absence of concerted and effective measures to hold the perpetrators of violations to account, it is unrealistic to expect that the problem will be resolved or that assistance actors can effectively address the issue of protection.

\section{Samangan massacre}

43. There were credible reports that Taliban forces under the command of Mullah Dadallah systematically executed ethnic Uzbek prisoners in Samagan Province in early May 2000. Accounts of the number of killings and precise burial sites vary, but the killings appear to have been large-scale and are reported to have taken place near the Rubatak Pass, along the road from Mazari-Sharif to Pul-i-Khumri. Those executed were variously reported to have been prisoners of war, Hazara conscripts who refused to serve with the Taliban and young men who had been arbitrarily detained in Samangan shortly before.

\section{$\underline{\text { Reported summary executions in Yakawlang }}$}

44. On 29 December 2000, Hezb-e-Wahdat forces captured Yakawlang, which was recaptured by the Taliban in early January 2001. According to the spokesman for the United Nations Secretary-General, after the Taliban captured Yakawlang, there were numerous reports of widespread summary executions of civilians by the Taliban, mostly in villages around Nayak, (the estimates range from one hundred to seven hundred) as well as mass arbitrary arrests. Eyewitnesses also reported that both parties to the conflict violated the neutrality of medical facilities in the district and generally disregarded the right of civilians to be treated as non-combatants. In addition, at least one United Nations employee is unaccounted for and has not been seen since 7 January. Aid agency personnel are reported to have been killed.

\section{B. $\quad$ Health}

45. A WHO Afghanistan paper on health priorities for action, presents the following statistics regarding the grim reality in the health sector: every day in Afghanistan about 45 women die of pregnancy-related causes and there are over 16,000 maternal deaths each year. Only about 15 per cent of deliveries are attended by trained health workers and more than 90 per cent of 


\section{E/CN.4/2001/43 \\ page 20}

births take place at home. Most of the maternal deaths are due to inadequate health services. Infectious diseases account for more than half of all premature deaths and disability, one of the chief causes of epidemics being the lack of safe drinking water and sanitary surroundings. Tuberculosis is a major killer of young adults. At least 15,000 Afghans die of tuberculosis each year; more than three fourths are young adults and 64 per cent are women. The impact of the ongoing conflict daily adds victims, both through physical violence and mental stress. It is estimated that 3 to 4 per cent of the population of Afghanistan are disabled to the point of needing some kind of service. While some progress has been made in establishing community-based health and rehabilitation committees extending rehabilitation services to around 100,000 disabled persons, these activities are restricted to only some geographical regions (60 out of 330 districts) and only a small proportion of the need even in the areas covered.

\section{Education}

46. A UNICEF Afghanistan paper entitled AEducation - a chronic emergency in Afghanistan $\cong$ records that after more than two decades of conflict, Afghanistan has some of the worst education indicators in the world. Access is low at all levels, especially for girls but also for boys. According to recent uNESCo data, as few as 3 per cent of Afghan girls and 39 per cent of boys in the relevant age groups may be receiving some form of primary education, the quality of much of which remains poor.

47. The ASG paper provides some hope for the future: there is a growing demand for education, including in rural areas where there is significant and increased support for girl children to go to school. But results cannot be expected overnight; long-term commitment is necessary.

\section{The media}

48. A report entitled Affghanistan: the Taliban and the media - a country with no news and pictures $=$ (September 2000), published by Reporters without Borders after a survey of the past and present situation, concludes: AAfghanistan today is one of the countries where absolutely no press freedom exists. The Taliban have extended and developed the policy of their predecessors, both the communists and the mujahideen. They totally control all means of communication and - like nowhere else in the world - they have banned pictures. This attitude deprives the Afghan people, scarred by more 
than 20 years of civil war, of seeing what their country and the world outside look like. This phobia of representing humanity and nature explain the Taliban militia-men=s relentless attacks on foreign journalists, cameramen and photographers seeking a visual record of a country that seems to have been thrust back into the Middle Ages:. Among the many specific cases cited, the most recent is that of the arrest of three foreign journalists on 11 August 2000 on the orders of the Taliban Deputy Minister for the Promotion of Virtue and Suppression of Vice on the charge of taking pictures of a football match. The journalists concerned were a Pakistani, Khawar Mehdi, a United States freelance photographer Jason Flario and a Brazilian reporter, Pepe Scobar, who said AThe religious police arrested us and interrogated us for two hours. They confiscated the photographer=s films, claiming we had broken their law, which forbids taking photos of living creatures.

\section{E. Women}

49. A document entitled ATake our words abroadミ, published by the women=s Commission for Refugee Women and Children (22 October 2000) and prepared with the support of United Nations office for the Coordination of Humanitarian Assistance in Afghanistan, with the disclaimer that it does not necessarily reflect the views of the United Nations system in Afghanistan, has recorded the views of a group of professional women in Kabul who continue to struggle to survive, some of which are reproduced below:

AThose people don=t know our problems and if and how women=s rights are being trampled in Afghanistan. If we know that the UN is defending our rights and backing us, then we would be willing to make sacrifices and to work under any conditions. As long as we feel we have support, we can work. The UN should take our words abroad. Those Afghan women who are advocating abroad speak with bare faces and they report hearsay. They=re not allowing women who are inside Afghanistan to participate and to express their problems.:

50. A report by the Senior United Nations Gender Adviser entitled AThe July 2000 Decree of Law on Female Employment (December 2000) records that during 1999 and the first quarter of 2000, a number of positive developments gave the assistance community signs that the severe restrictions on the education and employment of women were being slowly reconsidered by the authorities. The World Food Programme (WFP), for example, was able through patient negotiations 
E/CN.4/2001/43

page 22

to employ nearly 900 women in its surveys in Mazar-i-Sharif and Jalalabad. The UNDP PEACE programme employed 18 female teachers and two female monitors in Kandahar and Farah to work in community-based schools for girls and UNHCR managed to negotiate the return of its four female monitors in Kabul. The number of women working in public hospitals in all regions was on the increase. Preliminary figures indicate that in June 2000, nearly 1,000 female doctors and female workers were working with the assistance community while nearly 4,800 women were working in other occupational categories. These developments may seem insignificant to those who are not familiar with the complexity of the highly restrictive environment facing assistance programes in Afghanistan, but field workers who have a more informed memory of realities in the field welcomed what seemed a change of position on the part of the Taliban on female employment and considered them to be windows of opportunity that need to be sustained and strengthened.

\section{July 2000 Decree of Law on Female Employment}

51. A major setback occurred in July 2000 when the Taliban issued a decree banning Afghan women from working in aid agencies except in the health sector. The law not only represented a gross violation of the rights of Afghan women it also narrowed considerably the assistance community's access to more than 50 per cent of the Afghan population, since in Afghanistan only women aid workers can work with female beneficiaries.

52. The assistance community in Afghanistan was deeply disturbed by this new development. By the end of July, the United Nations Secretary-General issued a statement expressing concern over the issue. In July and August, the United Nations Coordinator and other senior United Nations staff made several visits to Kabul and Kandahar in an attempt to negotiate the withdrawal of the law. For their part, the donor community organized a march to the Afghan Embassy in Islamabad to express their concern and explain the possible negative implications of this restrictive law for donor assistance to the people of Afghanistan. Negotiations with the authorities on this issue are ongoing .

\section{F. $\quad \underline{\text { Food }}$}

53. WFP Afghanistan records that Afghanistan >s grain production has fallen by more than 50 per cent in the past two years and now meets less than half of total national grain requirements. Water tables are declining alarmingly in many parts of the country as a result of drought and excessive 
uncontrolled harvesting of ground water. Livestock herds, an important asset and safety net, have been severely depleted. Close to a million people are estimated to be vulnerable, hungry and at risk owing to loss of their agricultural output, combined with lack of other opportunities to earn enough money to pay for essential food.

54. The WFP Afghanistan paper perceptively underlines that: AThe absence of a well-functioning, development-oriented government in Afghanistan aggravates these problems, since some of the instruments normally used to promote food security - such as government-run safety nets, pricing policies, large irrigation and other infrastructure investments and agricultural research and extension - are not available.

55. A January 2001 report on a United Nations-sponsored health survey in northern Afghanistan has found alarming levels of malnutrition among children and aid officials warned that the situation could worsen dramatically in coming months. The survey, by the WFP and Action contre la faim (ACF) aid group found almost 10 per cent of children under the age of 30 months in the northern city of Mazar-i-Sharif to be suffering from acute malnutrition. The report stated that high rates of chronic malnutrition were widespread in Afghanistan owing to extreme poverty. Regular illness and a severe drought were exacerbating the problem. WFP had stepped up food distribution throughout Afghanistan but, as a result, its already limited resources were being strained. It planned to distribute some 20,000 tonnes of food per month and in addition needed 12,000 tonnes of food for 60,000 refugees. Its stocks were expected to run out by April 2001. WFP estimates at the end of January 2001 were that it needed 172,000 tonnes of food to continue its emergency operations for another year from April 2001. However, nternational donors, have failed to respond to an urgent appeal for 4.9 million dollars to help feed the 60,000 new Afghan refugees.

\section{E. New decree}

56. A decree was promulgated by Mullah Omar on 8 January 2001 to apply capital punishment to Afghans who converted from Islam to either Judaism or Christianity.

VI

NEED FOR A STRATEGY OF CHANGE

57. There can be little doubt that all segments of the Afghan population are united on the imperative need for change. As a United Nations office for 


\section{E/CN.4/2001/43 \\ page 24}

the Coordination of Humanitarian Assistance to Afghanistan report entitled: AVulnerability and humanitarian impact of UN Security Council sanctions in

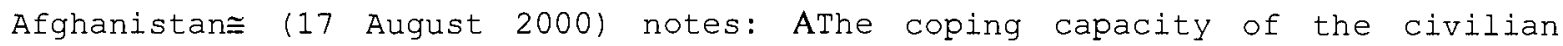
population has been severely weakenëd as a result of the war and the erosion of many traditional coping mechanisms, including in particular the role of extended family networks". The report also notes that the majority of the population is struggling to survive at near subsistence levels. According to several food security surveys, around 50 per cent of the population of Kabul (approximately 1.7 million) and other major urban centres are highly vulnerable. In other words, they fall below the WFP-determined minimum income level required per person per month to meet minimum food and essential nonfood needs. The level of vulnerability of rural areas remains an area of major concern. Throughout Afghanistan, the impact of the war on the economic infrastructure has been devastating. Transport and communication facilities are derelict. For Afghans, there are few job opportunities outside the subsistence economy on the one hand and the criminalized economy on the other.

58. The report observes that there is a strong consensus within Afghanistan on the need for the United Nations to upgrade and intensify its political engagement and peace-making efforts. Afghans from all walks of life have repeatedly queried why more is not being done to achieve peace and bring the war to an end.

59. The efforts of the Personal Representative of the Secretary-Gneral aimed at promoting a renewed peace process represent a significant United Nations initiative. The agreement signed by the Taliban and the United Front on 2 November 2000 was the first time the two warring sides have committed themselves in writing to a process of dialogue to achieve a political settlement, which suggests that they acknowledge that a military solution is not possible. It is also the first time that they have committed themselves not to abandon the negotiating process until all the items on the agenda have been examined. A distinctive feature of this agreement is that it is an agreement to a process, unlike earlier agreements which focused on the holding of meetings.

\section{CONCLUDING OBSERVATIONS}

60. It is important to underline that significant improvement in the overall human rights situation requires for a comprehensive strategy of carefully orchestrated and coordinated moves at both the macro and micro levels. The moves should not be seen as alternatives but as complementary. 


\section{E/CN.4/2001/43 \\ page 25}

Micro-level incremental measures must clearly be persevered with and humanitarian assistance provided to strengthen the coping mechanisms of the population. However, this cannot be a substitute for resolute action by the international community to bring about a basic framework change.

61. The need is clear for initiating and sustaining a process in which all segments of the Afghan population, inside and outside Afghanistan, can take part in devising and establishing participatory institutions, not only at the community but also at the national level. This framework would embrace institutions of governance which will meet the test that they are based on the consent of the population and enable it to participate in the making of laws and policies and in their implementation. Given the multi-ethnic character of Afghanistan, but also given that there is consensus among the various multiethnic groups that they are committed to a unified Afghanistan, the national institutions must be multi-ethnic, broad-based and truly representative. This should be the overriding aim and ultimate goal of a process of sustained negotiation undertaken in good faith.

62. The international community, acting in particular through the Security Council, would be expected to discharge its fundamental obligation to protect the people and territory of Afghanistan from external interference and from the destructive armed conflict, which continues to be externally supported. The sufferings of the Afghan people are compounded by its territory being used for various forms of cross-border criminal activity, including drug trafficking. It is an indispensable condition for an overall improvement in the human rights situation that effective action is taken to prevent such activities.

63. The concerns regarding the impact of sanctions must be assessed keeping in view their efficacy in protecting the territory and people of Afghanistan from such external abuse. Care should be taken to ensure that implementation of the sanctions does not in any way impair or affect the economic and social rights of ordinary Afghan women, men and children. The sanctions are not expected or intended to have an adverse impact on these rights. Sanctions provide an incentive to make progress towards peace. A historical example, which may be of the way in which sanctions provide incentives for the withdrawal of repressive measures, in that of South Africa, where sanctions were used to initiate and sustain a purposeful negotiating process and to create the conditions for it through the release of political detainees and the repeal of repressive laws. In the context of Afghanistan, the current developments could provide a powerful incentive for all to move forward with 
E/CN.4/2001/43

page 26

purposeful negotiations aimed at peace, and measured steps towards the emergence of a multi-ethnic, broad-based and truly representative government. 


\section{ANNES I}

EYEWITNESS ACCOUNT (JANUARY 2001) .OF CONDITIONS IN IDP CAMPS IN NORTHERN AEGHANISTAN

1. We stop in the middle of a huge valley near Mazar in North Afghanistan. A military building where all the windows have been closed by bricks stands in front of us. This is Mazar IDP camp No. 65.

2. A number of men are sitting outside the building in a circle. We get out of our cars and walk towards them. On the left a man in his seventies is crying bitterly. I ask our translator to ask the men why he was crying. The response was that he has lost his two grandsons that morning and preparations are being made for their burial near the camp.

3. We enter the camp. A strong smell fills the place, a smell of bodies and human secretion. The place is so dark one can hardly see. There is no light in this building: no electricity, no fire and no candles. It takes me some time to distinguish the figures around. We enter the first "opening" on our right. The room has no door, no windows or even a curtain that gives its occupants some privacy or protects them from the draught. It is freezing cold despite my warm clothes, heavy coat and the woollen scarf. Two dead children are lying in the middle of the room and a number of women and children are sitting around them. I ask who the mother is. Our translator asks and they point to a woman sitting on the left. Unlike the grandfather, she is not crying. She looks at us blankly as we all stares at her. "Were the children sick?" After some exchange between our translator and the other women he responds. "They were not sick. They died of cold. Also because there is no food that keeps the children and old people warm."

4. I move to the other room. I notice suddenly that the place is so quiet. I wonder how can it be when there are 150 families living in the building. A voice in me answers that perhaps deep desolation makes people silent. In the second room nine people are sitting on the cement floor. Near the door of the room a very sick teenage boy is lying on some kind of sheeting with a quilt covering him. He looks at us as we enter. He too, has the same kind of look as the mother who lost her two kids. I am told he is sick. This is why he has the one quilt the family has. Five children sit near the wall with their hands on their chests. They are shaking and looked very strange. For seconds I cannot tell why they look so strange. Then gradually it dawns on me. This 


\section{E/CN.4/2001/43}

\section{page 28}

is the very first time in my life I see NAVY BLUE CHILDREN. I have seen black children, white children, yellow children, coffee-coloured children, but never navy blue children.

5. And so we go from one room to another in Mazar IDP camp 65 building No. one, where 150 Afghan IDP families live. We leave for building No. 2. A number of women and children stand outside the building. They thought we were delivering food. I get out of the car and as I look at them, face after face, I realize that the children, who wear cotton clothes but no shoes or socks, DID have navy blue faces, navy blue hands and navy blue feet. A strong wind is blowing and everybody, including the members of our convoy, is shivering. I walked towards a very sick-looking child. He backs away from me with a frightened look on his face. I ask the translator to tell his mother that I do not intend to harm him. She pushes him towards me and when I touch his hand it feels like ice. I asked our translator to ask why the children are this strange colour. My translator, an Afghan, looks at me with a disbelieving look in his eyes. "They look blue because it's cold and because they do not have food." The old man who was crying in the other building approaches us with a little boy, holding his hand. He stands in front of me and starts speaking in Dari, $\mathrm{He}$ is still crying. I find myself crying too. It is heart-breaking to see very old people crying. Our translator informs us that the old man wants to tell us that this is the only grandson he has left and that he is afraid of losing him too.

6. They are out there, in Kabul, Herat, Kandahar, Mazar and Bamyan, nearly half a million internally displaced persons who have no shelter, no food, no clothing and who when they look at their children for the last time before they bury them may think that one more KG of flour or potatoes, a pair of woollen socks, a pair of shoes or a jacket might have saved their children from death. If you are troubled by this story, please pass it to all who may contribute to making the suffering of Afghan people known to the world. 
TEXT OF LETTERS DATED 29 JANUARY 2001 ADDRESSED TO THE HEAD OF THE TALIBAN COUNCIL, MULLAH MOHAMMAD OMAR, AND TO THE PRESIDENT OF THE ISLAMIC STATE OF AGHANISTAN, MR. BURHANUDDIN RABBANI, RELATING TO THE REPORTED SUMMARY EXECUTION OF CIVILIANS AND OTHER BREACHES OF INTERNATIONAL HUMANITARIAN LAW IN THE COURSE OF RESUMED ARMED HOSTILITIES IN THE YAKAWLANG AREA (DECEMBER 2000 JANUARY 2001)

I am extremely concerned about the reports that are now coming out of Yakawlang district in Hazarajat. I have received numerous accounts of civilians being deliberately attacked and killed and subjected to gross and systematic violations of their human rights.

It is reported that on 28-29 December 2000, United Front Hezb-e-Wahdat forces captured Yakawlang, which was subsequently recaptured by Taliban forces in the first week of January 2000. In the course of this offensive, it is reported that both conflicting parties showed utter disregard for the well-being of the civilian population.

The civilian population, I am informed from independent and reliable sources, did not participate in the armed hostilities and remained in their villages. However, it appears that the Taliban forces engaged in widespread summary executions and arbitrarily detained hundreds of civilians who are still unaccounted for. A United Nations staff member is still missing and it is reported that local humanitarian personnel are among those killed. It is also reported that United Front forces occupied a hospital and leprosy centre that was subsequently attacked by Taliban troops.

I would earnestly appeal to both sides to refrain from resumption of armed confict. I would also urge that immediate investigations be undertaken to identify those responsible for grave violations of human rights and international humanitarian law. Such violations give rise to international criminal responsibility.

I would like to visit the area and gather relevant information so that facts can be determined and appropriate action taken. In the meantime, I would appreciate receiving any information that the Taliban authorities could provide about the above-reported occurrences and measures taken to ensure that the right to life and the right not to be subjected to summary execution and arbitrary detention are protected. 
E/CN.4/2001/43

page 30

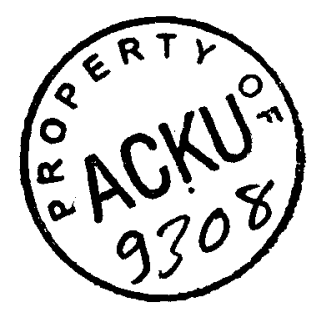

